\title{
Communication Gaps in Crisis Communication Management: Study at the Ministry of Transportation
}

\author{
$1^{\mathrm{st} *}$ Ari Sulistyanto \\ Faculty of Communication \\ Universitas Bhayangkara Jakarta Raya \\ Jakarta, Indonesia \\ ari.sulistyanto@dsn.ubharajaya.ac.id
}

\author{
$2^{\text {nd }}$ Achamd Jamil \\ Faculty of Communication \\ Universitas Mercu Buana \\ Jakarta, Indonesia \\ Achmad_jamil@mercubuana.ac.id
}

\begin{abstract}
The government organization, which is bureaucratic and hierarchical, tends to be slow in making decisions to respond to the crisis. This is caused by the communication gaps at the Sub-Sector level in its internal organization. This research aims to reveal the communication gaps in managing crisis communication in the internal organization of the Ministry of Transportation. The method of this research applies a literature review and Focus Group Discussion (FGD). The result of this research shows the establishment of the Crisis Communication Team as a medium to overcome the communication gaps among internal organizations in the Ministry of Transportation. This Crisis Communication Team is an Ad Hoc institution in which the Standard Operating Procedures (SOP) are arranged to create a consensus that begins at the pre-crisis phase, then crisis response phase, and ended at post-crisis phase.
\end{abstract}

\section{Keywords-Communication, Crisis, Gaps, Management}

\section{INTRODUCTION}

The Ministry of Transportation as a regulator of transportation often experiences some obstacles concerning crisis communication management and activity. Some of the examples were the sinking of Sinar Bangun ship in Toba Lake on June 18th, 2018, that killed three people and omitted 164 people and the fall of Lion Air plane JT 610 route Jakarta-Pangkal Pinang in Karawang water which caused all passengers and crews dead. In some of those examples, the Ministry of Transportation, as a government institution, is expected to overcome those problems responsively and fast by providing fast, precise, and accurate information. However, the Parliament valued slow the crisis communication management of the Ministry of Transportation concerning those cases. (Warta Ekonomi, October 29th, 2018) In hierarchical and bureaucratic organizations, such as government organizations are less adaptable to the rapid crisis response [1].

Against those cases, the management of crisis communication in government institutions becomes significant. What is at stake is the government's credibility, performance, and reputation in the eye of society [2]. Those government institutions which are responsible for disaster management should work collectively to make cohesive response plans[3]. However, the response in managing disaster was slow because of the communication gaps among Sub-Sector in the internal organization of the Ministry of Transportation. Consequently, some effects appear, such as lack of crisis identification, the absence of coordination among sections, and the lack of coordination between stakeholders and mass media, both in the selection of key personnel and critical messages to be delivered. As a result, the management of crisis communication becomes overlapping and not coordinated integrally.

In the management of public communication, the Ministry of Transportation supervises some Sub-Sectors, those are Sub-Sector of land, sea, air, and train. Each SubSectors owns a Division of Public Relations that aims to overcome public communication. Furthermore, the Public Relations of Ministry is positioned in an institution called Communication and Public Information Institution (BKIP), which is responsible for the Secretary-General.

The problem often faced with those organizational structures is the communication gaps, particularly concerning the absence of consensus about the need for crisis communication management that should be done if a disaster happens. For example, a disaster that happens in Sub-Sector of land like the plane accident. The public communication of this disaster, according to the job description, must be done by the Public Communication Division in the Sub-Sector of Air. However, because of the massive escalation of this disaster, the Communication and Public Information Institution (BKIP) becomes possessing an authority to overcome the crisis. At this condition, it occasionally occurs communication gaps in crisis identification and coordination in managing crisis communication.

By far, the research on communication gaps in crisis management has still limited among stakeholders. For example, the research on communication gaps in identifying crisis between the government's experts and NonGovernment Organization's experts show that communication has not been explicitly based on the practice of disaster management. Although there are crisis communication plans, best practice lists, and other guidance, communication as an integral part of decision making needs to be developed further [4]. Another essential research are, firstly, the gaps of information delivery through social media between regional government and residents affected by the disaster[5], secondly, the similarity and gaps in the perception of social media use to overcome crisis communication between Vietnam Government and NonGovernment Organization to guide crisis communication practice that is appreciated by the stakeholders [6]), and, thirdly, the understanding of response strategy towards crisis communication in a trade association [7].

Apart from the research above, some research on communication gaps focuses on the utilization of social media in decreasing communication gaps during the crisis. 
For example, when a prominent organization in Australia responds the crisis through social media, it does not own awareness on the potency of social media in helping crisis communication, and an organization sometimes does not respond stakeholders' messages or chosen crisis response strategy that could increase the reputation risk ([8]). The other research on communication gaps that focus on the utilization of social media in decreasing communication gaps when facing the crisis is, firstly, the use of social media in crisis communication of plane accident by analyzing online information to check whether the communication management is carried out effectively [9], and, secondly, the construction of online media towards crisis phenomena[10]. Social media has changed its view of the meaning of public participation and has become a platform for the Crisis Response Team to obtain credible information [11].

Those research still focuses on the external relation among stakeholders in controlling and managing crisis communication. However, the research that focuses on the exploration of communication gaps of internal organization in handling crisis communication management is still infrequently carried out.

In comprehending the reality of communication management that happens in internal organization, this research applies Situational crisis communication theory (SCCT) as a research framework. This theory, which is promoted by Coombs (2007), enables a researcher to examine the attribution of responsibility that influences the reputation of organization, shows the organization through response strategy [12], and adjusts with its authority in minimizing reputation threat toward organization caused by a crisis [13]. The SCCT theory is also used primarily to examine how reputation influences responsible for the organization and how response strategies protect reputations in accordance with the responsibilities held [14].

This theory holds a three-phase approach, ranging from the pre-crisis phase, crisis, and post-crisis phase [15]. Those phases are a set of factors that constitute the crisis management [16]. The pre-crisis phase includes the efforts to prevent crisis and the preparation of crisis management. The crisis phase is a response toward the actual phenomena [13] . Following this is the post-crisis phase that attempts to learn from crisis phenomena [14]. These categories reflect the phase of crisis communication management, which is beneficial because those categories provide a mechanism to consider the vast scope of crisis communication management. SCCT provides special attention to the adaptation of crisis strategy response with the aim of organization and the crisis types . Furthermore, SCCT utilizes the similarity between aims and crisis types to determine the proper recommendation of response strategy for an organization to create decisions in the crisis communication management. This is different from the High Response Organization (HRO) model, which emphasizes crisis resolution quickly [15]. This model emphasizes more on the crisis response phase.

Therefore, the problem carried on this research is how to overcome communication gaps that happen in the internal organization of the Ministry of Transportation in crisis communication management. This research owns practical significance towards the management of crisis communication in the organization, like the government bureaucrats could respond quickly and properly, both before and after a disaster occurs. Hence, it could minimize chronic crises, which can destroy the image and the reputation of the organization.

\section{Methodology}

This research applied a qualitative method. There were 2 steps in this research. The first step was a literature review about crisis communication management, including understanding and studying Laws, Presidential Decree, and Ministerial Regulation related to crisis communication management. The regulations studied are:

- The Regulation of the Minister of Transportation Number 122 of 2018 concerning Organization and Working Procedure of the Ministry of Transportation (State Gazette of the Republic of Indonesia 2018 Number 1756);

- The Regulation of the Minister of Transportation Number 38 of 2019 concerning Public Communication Management.

This step aimed to gain a juridical and practical base in handling crisis management, particularly in the Ministry of Transportation.

The second step was conducting Focus Group Discussion (FGD) with the Communication and Public Information Institution (BKIP) and Sub-Sector of Land, Sea, Air, and the Jabodetabek train management of the Ministry of Transportation. By conducting FGD means to get the data about the duty and authority of BKIP and Sub-Sector, involving the data of the pre-crisis phase, the decisionmaking of the establishment of Crisis Communication Team at the crisis phase, and the crisis recovery and reporting phase.

\section{RESULTS AND DISCUSSION}

\section{A. Crisis Communication Identification Phase}

This problem of the research is the communication gaps in managing crisis communication in the internal organization of the Ministry of Transportation. The results of the study found the need for the formation of a Crisis Communication Team to eliminate the communication gaps. Through the theoretical framework of the SCCT, in the precrisis stage, it was found that there was a need to identify the crisis first. Through this pre-crisis stage, it is an important beginning to form an understanding between the Public Relations Sub-Sector and the Public Information and Communication Agency (BKIP) in seeing the potential for crisis, and the urgency of whether or not crisis management is needed. Referring to the Regulation of Minister of Transportation Number 38 of 2019, the crisis communication management is implemented in the Ministry of Transportation if there is a transportation disaster or other potential crisis like the regulation of the implementation of transportation or the deviations of management that enable to distract the image, reputation, and trust of public toward the Ministry of Transportation. Regarding that regulation, it can be comprehended that the crisis can be divided into two; those are a communication crisis that can be anticipated, and a communication crisis that cannot be anticipated. So is the 
management of crisis communication, there are some phrases and procedures, like analyzing strategic issues, monitoring mass and social media, reporting news that has a potential crisis, and clarifying and countering issues to prevent the issues from being more severe.

The transportation disaster is a type of crisis that cannot be anticipated. In this crisis, the problem escalation happens incidentally, which needs a fast response. In the context of the Ministry of Transportation, the transportation disaster can be detailed as transportation of land, sea, air, train, and Jabodetabek train. Different from the management of crisis communication that can be anticipated, the problem escalation occurs gradually. As a result, the implementation of monitoring needs to be exercised to inventory the problems that can become a potential crisis. The type of problems in the Ministry of Transportation can be identified as bellows:

- Regulations that relate to transportation.

- Transportation accident.

- Congestion.

- Rise of the ticket's price.

- Corruption Handling Operation.

- And others.

The management of crisis communication is a cycle that begins with the normal condition of transportation management, then it potentially changes into crisis condition, and finally back to the normal condition [16] . Therefore, the understanding of crisis communication potency becomes significant. Because of the urgency of managing crisis communication, understanding crisis communication is described in the following parameters:

- Negative reporting from various mass media.

- Negative discussions and opinions in social media and online media, and or

- Phenomena that tarnish the image and the reputation of the institution and cause victims, physical damage, material losses, and other negative impacts.

Understanding the potential crisis, its most significant percentage falls in conducting monitoring toward mass media and online media through some stages as follow:

- Conducting monitoring toward mass media, both printed and online media that contain negative news.

- Determining attribute or tone which occurs like positive, neutral, or negative.

- The result from point 2 is prioritizing the significant issues from mass media or online media, which is then transformed to detect the tendency of attributes whether it moves negatively and extends, or narrows in a neutral and positive direction. The consideration of potential crisis is wholly based on the assertion of the Data Monitoring Division in the Communication and Public Information Institution (BKIP) that is fully supported by previous experiences on empirical phenomena or potential crisis incidents.

\section{B. Pre-Crisis Phase}

The pre-crisis phase involves signal detection, prevention, and preparation [17]. At the early detection stage, because the Crisis Communication Team has not been established yet, the task responsibility is on Sub-Sector of BKPIP, particularly on Sub-Division of Planning and Communication Strategy and Sub-Division of Communication Program Evaluation Analysis that is responsible for conducting monitoring the information concerning the availability of potential crisis.

The early detection of the potential crisis becomes a part of public communication management at the pre-crisis phase. Monitoring on the potential crisis or pre-crisis and countering issues become the responsibility of each SubSector's Public Relations of the Ministry of Transportation is done permanently and regularly.

The Sub-Division of Communication Program Evaluation Analysis is responsible for monitoring the data and analyzing it based on early information concerning the potential crisis of transportation disaster. The information that resulted from media monitoring become primer and seconder data. The coordination can be practiced with other stakeholders in the scope of the Ministry of Transportation like Basarnas, National Transportation Accident Commission (KNKT), Regional Transportation Department, Airports, Harbors, and others. The coordination among stakeholders contains information and news about the potential crisis transportations that are monitored by those stakeholders or working units.

When there are findings from Sub-Sectors and based on monitoring, the BKIP's results show the escalation of negative issues until a strategic macro level that is crosssectorial and has national and international impacts. The Chief of BKIP delivers it to the Minister of Transportation through Ministry Secretary-General and suggests for the establishment of a crisis management institution. This condition becomes a beginning to conduct communication through a meeting attended by Sub-Sectors of the Ministry of Transportation. The meeting's result states that it is necessary to conduct crisis management. So, it then should be followed by a preparation phase and crisis communication planning by establishing a Crisis Communication Team as an Ad Hoc institution.

The operational procedures concerning the pre-crisis phase can be seen in table 1, which explains the sequence of duty description, duty executors, time, and the results of the duty.

TABLE I. Standard OPERATING Procedure ON PRE-CRISIS PHASE

\begin{tabular}{|l|l|l|l|}
\hline \multicolumn{1}{|c|}{ Description } & \multicolumn{1}{|c|}{$\begin{array}{c}\text { Duty } \\
\text { Executor }\end{array}$} & Duration & Output \\
\hline $\begin{array}{l}\text { To instruct the Sub-Sectors } \\
\text { of BKIP to conduct } \\
\text { monitoring and collecting } \\
\text { the information data and } \\
\text { analyze the data } \\
\text { concerning the availability } \\
\text { of potential crisis }\end{array}$ & $\begin{array}{l}\text { Seneral } \\
\text { Inspector } \\
\text { General } \\
\text { Director- } \\
\text { General } \\
\text { Chief } \\
\text { Institution of }\end{array}$ & Periodical & $\begin{array}{l}\text { Dispositi } \\
\text { on }\end{array}$ \\
\hline $\begin{array}{l}\text { To conduct monitoring } \\
\text { information through mass } \\
\text { media and social media }\end{array}$ & $\begin{array}{l}\text { Public } \\
\text { Information } \\
\text { Communicati }\end{array}$ & I & $\begin{array}{l}\text { Periodica } \\
\text { of } \\
\text { monitori }\end{array}$ \\
\hline
\end{tabular}




\begin{tabular}{|c|c|c|c|}
\hline $\begin{array}{l}\text { concerning the existence } \\
\text { of a potential crisis }\end{array}$ & $\begin{array}{l}\text { on Institution } \\
\text { (BKIP) } \\
\text { Sub-Sector }\end{array}$ & & $\begin{array}{l}\text { ng media } \\
\text { result }\end{array}$ \\
\hline $\begin{array}{l}\text { To analyze and predict the } \\
\text { availability of potential } \\
\text { crisis }\end{array}$ & $\begin{array}{l}\text { Public } \\
\text { Information } \\
\text { Communicati } \\
\text { on Institution } \\
\text { (BKIP) } \\
\text { Sub-Sector }\end{array}$ & $\begin{array}{l}\text { Periodica } \\
\text { I }\end{array}$ & Report \\
\hline $\begin{array}{l}\text { To report based on an } \\
\text { analysis of the availability } \\
\text { of potential crisis that will } \\
\text { be broadened }\end{array}$ & $\begin{array}{l}\text { Public } \\
\text { Information } \\
\text { Communicati } \\
\text { on Bureau } \\
\text { (BKIP) } \\
\text { Sub-Sector }\end{array}$ & 1 hour & $\begin{array}{l}\text { Report } \\
\text { and } \\
\text { analyzing } \\
\text { the result }\end{array}$ \\
\hline $\begin{array}{l}\text { To conduct a meeting } \\
\text { between BKIP and Sub- } \\
\text { Sectors }\end{array}$ & $\begin{array}{l}\text { Secretary- } \\
\text { General } \\
\text { Inspector } \\
\text { General } \\
\text { Director- } \\
\text { General } \\
\text { Chief of } \\
\text { Institution } \\
\text { Sub-Sector }\end{array}$ & 1 hour & $\begin{array}{l}\text { Report } \\
\text { and } \\
\text { meeting }\end{array}$ \\
\hline $\begin{array}{l}\text { To decide and establish a } \\
\text { Crisis Communication } \\
\text { Team }\end{array}$ & $\begin{array}{l}\text { Secretary- } \\
\text { General } \\
\text { Inspector } \\
\text { General } \\
\text { Director- } \\
\text { General } \\
\text { Chief of } \\
\text { Institution }\end{array}$ & 1 hour & $\begin{array}{l}\text { Recomm } \\
\text { endation, } \\
\text { Decision, } \\
\text { and Crisis } \\
\text { Communi } \\
\text { cation } \\
\text { Team }\end{array}$ \\
\hline $\begin{array}{l}\text { To determine the } \\
\text { personnel executors of the } \\
\text { Crisis Communication } \\
\text { Team }\end{array}$ & $\begin{array}{l}\text { Inspector } \\
\text { General } \\
\text { Director- } \\
\text { General } \\
\text { Chief of } \\
\text { Institution } \\
\text { Sub-Sector }\end{array}$ & 1 hour & $\begin{array}{l}\text { Letter of } \\
\text { assignme } \\
\text { nt }\end{array}$ \\
\hline $\begin{array}{l}\text { To conduct preparation } \\
\text { and coordination and to } \\
\text { provide basic facilities for } \\
\text { the Crisis Communication } \\
\text { Team }\end{array}$ & $\begin{array}{l}\text { Administratio } \\
\mathrm{n} \text { Sector }\end{array}$ & 1 hour & $\begin{array}{l}\text { Equipme } \\
\mathrm{nt}\end{array}$ \\
\hline
\end{tabular}

\section{Crisis Response Phase}

The Crisis Communication Team is established as a cross-sectorial Ad Hoc Working Unit, which involves the staff of a cross-working unit with clear duty separation and authority. Procedurally, the Chief of Crisis Communication Tem as a leader that activates the team by placing staff from other deputies based on function, competence, and scope of the crisis that occurs. The placement of personnel in each organizational post refers to organizational structures and duty-authority that have been made.

The procedure is implemented to bring the normal situation back. This can be seen from monitoring results of the Division of Communication Program Evaluation Analysis based on the movement of crisis parameters, which goes down. The operational practice in the crisis response phase can be seen in Table 2 .
TABLE II. STANDARD OPERATING PROCEDURE ON CRISIS RESPONSE PHASE

\begin{tabular}{|c|c|c|c|}
\hline Job Description & $\begin{array}{c}\text { Duty } \\
\text { Executor }\end{array}$ & $\begin{array}{c}\text { Durati } \\
\text { on }\end{array}$ & Output \\
\hline $\begin{array}{l}\text { Early coordination } \\
\text { meeting of the Crisis } \\
\text { Communication Team }\end{array}$ & $\begin{array}{l}\text { Secretary- } \\
\text { General } \\
\text { Inspector } \\
\text { General } \\
\text { Director- } \\
\text { General } \\
\text { Chief of } \\
\text { Institution } \\
\text { Crisis } \\
\text { Communicati } \\
\text { on Team } \\
\text { Division of } \\
\text { Monitoring } \\
\text { Information } \\
\text { and Data } \\
\text { Analysis } \\
\text { Administratio } \\
n \text { Sector } \\
\text { Media Sector }\end{array}$ & 1 hour & $\begin{array}{l}\text { Report and } \\
\text { meeting }\end{array}$ \\
\hline $\begin{array}{l}\text { To prepare Crisis Center } \\
\text { facilities }\end{array}$ & $\begin{array}{l}\text { Administratio } \\
\text { n Sector }\end{array}$ & 1 hour & $\begin{array}{l}\text { Preparedne } \\
\text { ss of crisis } \\
\text { center }\end{array}$ \\
\hline $\begin{array}{l}\text { To arrange Holding } \\
\text { Statement and be } \\
\text { continued by disposition } \\
\text { from first Chief of Crisis } \\
\text { Communication Team }\end{array}$ & $\begin{array}{l}\text { Crisis } \\
\text { Communicati } \\
\text { on Team } \\
\text { Division of } \\
\text { Monitoring } \\
\text { Information } \\
\text { and Data } \\
\text { Analysis }\end{array}$ & 1 hour & $\begin{array}{l}\text { Draft } \\
\text { Holding } \\
\text { Statement }\end{array}$ \\
\hline $\begin{array}{lr}\text { To } & \text { determine } \\
\text { spokesman/spokeswoman }\end{array}$ & $\begin{array}{l}\text { Crisis } \\
\text { Communicati } \\
\text { on Team } \\
\text { Media Sector }\end{array}$ & 1 hour & $\begin{array}{l}\text { Holding } \\
\text { Statement }\end{array}$ \\
\hline $\begin{array}{l}\text { To distribute information } \\
\text { to various stakeholders } \\
\text { like printed media, } \\
\text { electronic media, and } \\
\text { online media }\end{array}$ & $\begin{array}{l}\text { Division of } \\
\text { Monitoring } \\
\text { Information } \\
\text { and Data } \\
\text { Analysis } \\
\text { Administratio } \\
\text { n Sector } \\
\text { Media Sector }\end{array}$ & 1 hour & $\begin{array}{l}\text { Distribution } \\
\text { of } \\
\text { information }\end{array}$ \\
\hline $\begin{array}{l}\text { To distribute information } \\
\text { to the internal of the } \\
\text { Ministry of Transportation }\end{array}$ & $\begin{array}{l}\text { Administratio } \\
\text { n Sector } \\
\text { Media Sector }\end{array}$ & 1 hour & $\begin{array}{l}\text { Distribution } \\
\text { of } \\
\text { information }\end{array}$ \\
\hline $\begin{array}{lr}\text { To conduct } & \text { coordination } \\
\text { concerning } & \text { new } \\
\text { information about } & \text { crisis } \\
\text { development } & \end{array}$ & $\begin{array}{l}\text { Division of } \\
\text { Monitoring } \\
\text { Information } \\
\text { and Data } \\
\text { Analysis } \\
\text { Administratio } \\
\text { n Sector } \\
\text { Media Sector }\end{array}$ & $\begin{array}{l}\text { Regula } \\
r\end{array}$ & $\begin{array}{l}\text { Analysis } \\
\text { result }\end{array}$ \\
\hline $\begin{array}{l}\text { To report regularly about } \\
\text { crisis development }\end{array}$ & $\begin{array}{l}\text { Chief of Crisis } \\
\text { Communicati } \\
\text { on Team } \\
\text { Division of } \\
\text { Monitoring } \\
\text { Information }\end{array}$ & $\begin{array}{l}\text { Regula } \\
r\end{array}$ & $\begin{array}{l}\text { Analysis } \\
\text { result }\end{array}$ \\
\hline
\end{tabular}




\begin{tabular}{|c|c|c|c|}
\hline & $\begin{array}{l}\text { and Data } \\
\text { Analysis } \\
\text { Administratio } \\
\text { n Sector } \\
\text { Media Sector }\end{array}$ & & \\
\hline $\begin{array}{l}\text { To conduct coordination } \\
\text { and planning of press } \\
\text { broadcast regularly after } \\
\text { holding statement } \\
\text { published }\end{array}$ & $\begin{array}{l}\text { Chief of Crisis } \\
\text { Communicati } \\
\text { on Team } \\
\text { Division of } \\
\text { Monitoring } \\
\text { Information } \\
\text { and Data } \\
\text { Analysis } \\
\text { Administratio } \\
\text { n Sector } \\
\text { Media Sector }\end{array}$ & $\begin{array}{l}\text { Regula } \\
r\end{array}$ & $\begin{array}{l}\text { Press } \\
\text { statement } \\
\text { draft }\end{array}$ \\
\hline Press conference regularly & $\begin{array}{l}\text { Chief of Crisis } \\
\text { Communicati } \\
\text { on Team } \\
\text { Administratio } \\
\mathrm{n} \text { Sector } \\
\text { Media Sector } \\
\text { Spokesman/s } \\
\text { pokeswoman }\end{array}$ & $\begin{array}{l}\text { Regula } \\
r\end{array}$ & $\begin{array}{l}\text { Press } \\
\text { statement } \\
\text { Twice a day } \\
\text { if necessary }\end{array}$ \\
\hline Daily report & $\begin{array}{l}\text { Administratio } \\
\mathrm{n} \text { Sector }\end{array}$ & $\begin{array}{l}\text { Regula } \\
r\end{array}$ & $\begin{array}{l}\text { Report } \\
\text { result }\end{array}$ \\
\hline
\end{tabular}

\section{D.Post-Crisis Phase and Reporting}

Post-crisis phase is the ending stage of handling crisis based on crisis level parameter that has gone down or back to normal condition. It means the crisis status in the Ministry of Transportation has been revoked according to some considerations, which are decided by the Chief of Crisis Communication Team. Those considerations are the crisis has passed through the peak phase, there are planning of prevention and responsible people for damage or crisis impact in the recovery phase, the victims have been handled, and the frequency of news in mass media and online media have descended. The mechanism of work in the post-crisis phase can be seen in table 3 .

TABLE III. STANDARd OPERATING PROCEDURE ON POST-CRISIS PHASE

\begin{tabular}{|l|l|l|l|}
\hline \multicolumn{1}{|c|}{ Job Description } & Duty Executor & \multicolumn{1}{|c|}{$\begin{array}{c}\text { Durati } \\
\text { on }\end{array}$} & Output \\
\hline $\begin{array}{l}\text { To instruct the } \\
\text { administration } \\
\text { sector to conduct } \\
\text { Crisis } \\
\text { Communication }\end{array}$ & $\begin{array}{l}\text { Chief of Crisis } \\
\text { Communication } \\
\text { Team }\end{array}$ & 1 hour & $\begin{array}{l}\text { Warrant } \\
\text { disposition }\end{array}$ \\
Team meetings & $\begin{array}{l}\text { To distribute a letter } \\
\text { of invitations to all } \\
\text { members of the } \\
\text { Crisis } \\
\text { Communication } \\
\text { Team coctor }\end{array}$ & 1 hour & $\begin{array}{l}\text { Letter of } \\
\text { invitation }\end{array}$ \\
\hline $\begin{array}{l}\text { To onduct } \\
\text { meetings and } \\
\text { decide the working } \\
\text { period of Crisis } \\
\text { Communication }\end{array}$ & $\begin{array}{l}\text { Chief of Crisis } \\
\text { Communication } \\
\text { Team which has }\end{array}$ & $\begin{array}{l}\text { Divion hour } \\
\text { Information and }\end{array}$ & $\begin{array}{l}\text { A decision } \\
\text { on ending } \\
\text { of the crisis }\end{array}$ \\
\hline
\end{tabular}

\begin{tabular}{|c|c|c|c|}
\hline ended & $\begin{array}{l}\text { Data Analysis } \\
\text { Administration } \\
\text { Sector } \\
\text { Media Sector }\end{array}$ & & \\
\hline $\begin{array}{l}\text { Media sector stops } \\
\text { information service }\end{array}$ & Media Sector & 1 hour & Non-active \\
\hline $\begin{array}{l}\text { The administration } \\
\text { sector ensures all } \\
\text { resources which are } \\
\text { used during crisis } \\
\text { handling has been } \\
\text { deactivated and all } \\
\text { divisions which are } \\
\text { involved in the Crisis } \\
\text { Communication } \\
\text { Team back to each } \\
\text { division. }\end{array}$ & $\begin{array}{l}\text { Administration } \\
\text { Sector }\end{array}$ & 1 hour & Non-active \\
\hline $\begin{array}{l}\text { The administration } \\
\text { sector coordinates } \\
\text { with and informs } \\
\text { the external sector } \\
\text { that the crisis has } \\
\text { ended, and the } \\
\text { condition has } \\
\text { deactivated. }\end{array}$ & $\begin{array}{l}\text { Administration } \\
\text { Sector }\end{array}$ & $\begin{array}{l}1-3 \\
\operatorname{day}(\mathrm{s})\end{array}$ & $\begin{array}{l}\text { Report per } \\
\text { sector }\end{array}$ \\
\hline $\begin{array}{l}\text { The administration } \\
\text { sector coordinates } \\
\text { all members of the } \\
\text { Crisis } \\
\text { Communication } \\
\text { Team to make } \\
\text { reports. }\end{array}$ & $\begin{array}{l}\text { Administration } \\
\text { Sector }\end{array}$ & $\begin{array}{l}1-3 \\
\operatorname{day}(\mathrm{s})\end{array}$ & $\begin{array}{l}\text { Report per } \\
\text { sector }\end{array}$ \\
\hline $\begin{array}{l}\text { The administration } \\
\text { sector compiles } \\
\text { reports. }\end{array}$ & $\begin{array}{l}\text { Administration } \\
\text { Sector }\end{array}$ & $\begin{array}{l}1-3 \\
\operatorname{day}(\mathrm{s})\end{array}$ & $\begin{array}{l}\text { Complete } \\
\text { report }\end{array}$ \\
\hline $\begin{array}{l}\text { The administration } \\
\text { sector conducts } \\
\text { filling toward all } \\
\text { documents during } \\
\text { the activities of the } \\
\text { Crisis } \\
\text { Communication } \\
\text { Team. }\end{array}$ & $\begin{array}{l}\text { Administration } \\
\text { Sector }\end{array}$ & $\begin{array}{l}1-3 \\
\operatorname{day}(\mathrm{s})\end{array}$ & $\begin{array}{l}\text { Complete } \\
\text { report }\end{array}$ \\
\hline Reporting & $\begin{array}{l}\text { Chief of Crisis } \\
\text { Communication } \\
\text { Team }\end{array}$ & & $\begin{array}{l}\text { Document } \\
\text { of the } \\
\text { complete } \\
\text { report }\end{array}$ \\
\hline
\end{tabular}

The result of research found that the establishment of the Crisis Communication Team is a medium to overcome communication gaps in managing crisis communication. The significant problem in crisis communication management is communication [18]. The personnel of the team, which came from cross-sectorial, eased interaction and communication in doing response and recovery. As a result, the condition could become normal quickly.

The Ministry of Transportation, as a bureaucratic organization, will be difficult to respond quickly to the disaster that tends to be a crisis. This situation is common, especially in organizations that are used to hierarchy, and centralized decision making has to work suddenly in ad-hoc organizations that are flatter and more dynamic [19]. So are the organizations that supervise many different Sub-Sectors do not only homogenous entity but also consist of subgroups with different interest, aim, agenda, and priority [8].

The application of Situational crisis communication theory (SCCT) as a theoretical framework in managing crisis 
communication has practical significance to overcome communication gaps in the internal organization of the Ministry of Transportation. The existence of the pre-crisis phase, which revolves around collecting information about crisis risk, becomes a medium of interaction for the stakeholders of the internal of the Transportation Ministry to identify and decide solutions on how to handle a potential crisis.

In the pre-crisis phase, crisis communication concentrates on placing and decreasing the risk. Prevention is the main priority for this anticipative model [15]. This model uses alertness during the pre-crisis phase to help decision-making and crisis prevention. Wan and Pfau (2004) recommended the use of pre-crisis messages to encourage the stakeholders about the crisis [5]. By using a biological analogy, the precrisis messages give the stakeholders in Sub-Sectors of the Ministry of Transportation some information about the potential crisis to help and build resistance toward adverse reactions and negative media reportage.

In the crisis response phase, the establishment of the Crisis Communication Team became a momentum in eliminating the communication gaps in crisis communication management. This is because the personnel of the Crisis Communication Team was a combination of all Sub-Sectors in the internal organization of the Ministry of Transportation. The Crisis Communication Team became a medium to cooperate and coordinate to save the reputation and the image of the organization. This is in line with SCCT as a theoretical framework which stated that the reaction of stakeholders toward crisis consequences the behaviors for the organization and that what is practiced or stated by the organization during a crisis can influence its reputation [20].

SCCT is different from high- reliability organizations (HRO) theory operates in an uncertain crisis or emergency conditions[21]. HRO theory provides a practical framework for complex organizations to work reliably in uncertain situations. This theory helps to organize and analyze the routines, policies, procedures, and strategies behind communication decisions in ways that have never been applied before. This theoretical framework had succeeded in overcoming crisis communication when Bomb Bali I and II happened[18].

\section{CONCLUSION}

In minimizing communication gaps and gaining collective understanding in facing the crisis, it is necessary to establish a Crisis Communication team as a medium of communication from various Sub-Sectors of the Ministry of Transportation. This team then arranges Standard Operating Procedure (SOP) as a form of collective understanding in facing the crisis. SOP is a mechanism of regulation in managing crisis communication that consists of three phases. Those phases begin with a pre-crisis phase that aims to anticipate and detect the crisis, then followed by a crisis response phase whose purpose is to overcome the crisis by establishing an ad hoc crisis communication institution, ended with the post-crisis phase, which focuses on crisis recovery.

Hopefully, the findings in this research can contribute to managing crisis communication in bureaucratic organizations. However, there is still a limitation in this research: the focus of this research is communication gaps among Sub-Sectors in the internal organization of the Ministry of Transportation. Whereas, when the disaster happens, which impacts on crisis communication, the Ministry of Transportation is not only the entity responsible for the disaster. There are other institutions outside the Ministry of Transportation that responsible for the disaster like BASARNAS and National Transportation Safety Committee (NTSC). Therefore, further research can be focused on the communication gaps between the Ministry of Transportation and external organizations in managing crisis communication.

\section{REFERENCES}

[1] B. Y. B. S. Manoj and A. H. Baker, "Communication challenges in emergency response," Comun. ACM, vol. 50, no. 3, pp. 51-53, 2007.

[2] M. J. Al Shobaki, Y. M. Abu Amuna, and S. S. Abu Naser, "The impact of top management support for strategic planning on crisis management: Case study on UNRWA-Gaza Strip," Int. J. Acad. Res. Dev., vol. 10, no. 2, pp. 20-25, 2016.

[3] D. P. Eisenman, K. M. Cordasco, S. Asch, J. F. Golden, and D. Glik, "Disaster Planning and Risk Communication With Vulnerable Communities : Lessons From Hurricane Katrina," vol. 97, no. 1, pp. 109-115, 2007, doi: 10.2105/AJPH.2005.084335.

[4] J. Kádárová, B. Mihalčová, G. Kádár, and M. Vida, "Strategy Map for the Crisis Communication," Procedia Econ. Financ., vol. 23, no. October 2014, pp. 1119-1124, 2015, doi: 10.1016/s22125671(15)00518-3

[5] L. Hong, C. Fu, J. Wu, and V. Frias-Martinez, "Information Needs and Communication Gaps between Citizens and Local Governments Online during Natural Disasters," Inf. Syst. Front., vol. 20, no. 5, pp. 1027-1039, 2018, doi: 10.1007/s10796-018-9832-0.

[6] T.-M. Ly-Le, "Gaps in Perception on Social Media Use in Crisis Communication Between Vietnamese Organizations and Stakeholders," DeReMa (Development Res. Manag. J. Manaj., vol. 13, no. 1, p. 11, 2018, doi: 10.19166/derema.v13i1.768.

[7] F. Frandsen and W. Johansen, "Voices in Conflict? The Crisis Communication of Meta-Organizations," Manag. Commun. Q., vol. 32, no. 1, pp. 90-120, 2018, doi: 10.1177/0893318917705734.

[8] M. Roshan, M. Warren, and R. Carr, "Understanding the use of social media by organisations for crisis communication," Comput. Human Behav., vol. 63, pp. 350-361, 2016, doi: 10.1016/j.chb.2016.05.016.

[9] D. R.-T. and Y. Dominguez-Lopez, "Social Media in Crisis Communication: Germanwings Flight 4U9525 Diego," in Media and metamedia management, Advances in Intelligent Systems and Computing 503, F.C. Freire et al. (eds.), Ed. Springer International Publishing Switzerland 2017, 2017, pp. 243-249.

[10] J. Zeng, C. H. Chan, and K. W. Fu, "How Social Media Construct 'Truth' Around Crisis Events: Weibo's Rumor Management Strategies After the 2015 Tianjin Blasts," Policy and Internet, vol. 9, no. 3, pp. 297-320, 2017, doi: 10.1002/poi3.155.

[11] M. Collins et al., "Communication in a disaster - the development of a crisis communication tool within the S-HELP project," vol. 0125, no. June, 2016, doi: 10.1080/12460125.2016.1187392.

[12] W. T. Coombs, "Parameters for Crisis Communication," in The Handbook of Crisis Communication, First., Combs and Haliday, Ed. Blackwell Publishing Ltd, 2010, pp. 17-53.

[13] G. L. Adkins, "Organizational Networks in Disaster Response: An Examination of the US Government Network's Efforts in Hurricane Katrina," in The Handbook of Crisis Communication, Fisrt., Coombs and Holladay, Ed. 2010 Blackwell Publishing Ltd, 2010, pp. 93-114.

[14] L. Ma and M. (Monica) Zhan, "Effects of attributed responsibility and response strategies on organizational reputation: A meta-analysis of situational crisis communication theory research," J. Public Relations Res., vol. 28, no. 2, pp. 102-119, 2016, doi: 10.1080/1062726X.2016.1166367.

[15] G. L. Adkins, The Handbook of Crisis Communication. Blackwell Publishing Ltd Blackwell, 2010. 
[16] P. Vardarler, "Strategic Approach to Human Resources Management During Crisis," Procedia - Soc. Behav. Sci., vol. 235, no. October, pp. 463-472, 2016, doi: 10.1016/j.sbspro.2016.11.057.

[17] J. Bundy, M. D. Pfarrer, C. E. Short, and W. T. Coombs, Crises and Crisis Management: Integration, Interpretation, and Research Development, vol. 43, no. 6. 2017.

[18] E. K. Dougall, J. S. Horsley, and C. McLisky, "Disaster Communication: Lessons from Indonesia," Int. J. Strateg. Commun., vol. 2, no. 2, pp. 75-99, 2008, doi: 10.1080/15531180801958188.

[19] W. and S. J. Coombs, T. Holladay, The Handbook of Crisis Communication. The Atrium, Southern Gate, Chichester, West Sussex, PO19 8SQ, United Kingdom: John Wiley \& Sons Ltd, 2010.

[20] A. van Rensburg, D. Conradie, and H. Dondolo, "the Use of the Situational Crisis Communication Theory To Study Crisis Response Strategies At a University of Technology," Communitas, vol. 22, no. 1, pp. 62-74, 2017, doi: 10.18820/24150525/comm.v22.5.

[21] A. E. Agwu, A. Labib, and S. Hadleigh-Dunn, "Disaster prevention through a harmonized framework for high reliability organisations," Saf. Sci., vol. 111, no. December 2017, pp. 298-312, 2019, doi: 10.1016/j.ssci.2018.09.005 